Laramie group, an extensive brackish water formation in Western North America, which holds a transitional position between the Mesozoic and Cenozoic series. Associated with Pyrgulifera humerosa, among various other fresh and brackish. water forms, is one that I have described under the name of Goniobasis cleburni, which is evidently congeneric with the Melania (Sermyla) admirabilis of Smith, an associate of Pyrgulifera damoni and $P$. crassigranulata in Lake Tanganyika. As that lake has evidently once been a brackish water sea, it is not strange that there should be certain similarities between its molluscan fauna and the faunæ of similar bodies of water that existed in Mesozoic and Cenozoic time. It is, however, remark. able that the two generic types here especially referred to should appear in their integrity living in Africa, and not in North America, where the fossil forms occur ; and especially so because so many of the fresh-water and land-molluscan types now living on the latter continent are found fossil in its Mesozoic and Cenozoic strata.

Washington, D.C., November 4

\section{Velocity of Wind}

THE following observations regarding the velocity of the wind in the south-west gale of the 2 Ist and 22 nd of November at Edinburgh may be of interest. The observations were made by me about nine o'clock on the morning of the 22 ad, when the wind had somewhat moderated :-

Mean velocity

Velocity during a squall ...

Miles per hour. $62 * 3$

These observations are calculated from the velocity of clouds of smoke issuing from the chimney of the Caledonian Distillery, and travelling for a distance of 2100 feet, and are thus free from instrumental errors. The chimney is 225 feet high, and its base is about 200 feet above the sea-level.

Charles Alex. Stevenson

\section{Arctic Research}

No one can hold in higher honour and respect than ' $I$ do the opinions of the greatest of Arctic navigators, Sir Edward Parry, although these opinions were expressed more than half a century ago, since when our knowledge of Arctic shores has very materially increased.

My letter in NATuRE vol. xxv. p. 53, where alluding to navigable waters through channels, \&c., in the Arctic Sea specially referred to Arctic America and the lands lying north of it, in which category Greenland can scarcely be included, certainly not that part of its western shores along which a navigable passage is almost invariably to be found.

The following passages from the extract from "Sir Edward Parry's writings" (NATURE, vol. xxv. p. 78) are those which specially bear upon the statements made by me :-

"We experienced a striking example of this kind [ice obstruction] in coasting the eastern shore of Melville Peninsula in I822 and 1823 , the whole of the coast being so loaded with ice as to make the navigation extremely difficult and dangerous."

I do not in the least doubt this, but difficulties of ice-navigation are comparative, and I believe from Eskimo report that the opposite side of Fox's Channel would have been worse. On asking the natives of Repulse Bay why they did not go over to Southampton Island, which forms the eastern shore (having a western aspect) of Sir 'Thomas Roe's Welcome, the reply was, there were no seals or walruses there, the ice being too much on shore. The same is said of the east side of Fox's Channel.

The sea on the west side of Melville Peninsula is said never to be free from ice ${ }^{1}$; such was its condition during the summer of $\mathbf{1} 846$; and in 1847 , when I traced its whole shore, there was a fringe of heavy and rugged hummocks some miles wide all the way.

In the springs of $\mathbf{I} 847$ and $\mathbf{1} 854$ the opposite coast, being the west side of Committee Bay-having an eastern aspect-bore evidence, by the small quantity of rough ice met with, that there had been navigable water at some time during the previous summer.

There can, as a rule, be no better or truer guide to the side of a channel, inlet, \&c., which is least ice-obstructed than the assembling of marine animals, seals, walruses, and whales (provided always that these animals have not been driven away by constant attacks to less favoured resorts) along its shores, on which the Eskimos have their chief camping-grounds, and of

$$
\text { I See Rae's "Arctic Expedition," 1846-7, p. } 49 .
$$

which there are many along the east shore of Melville Peninsula and southward on the same coast-line to lat. $64^{\circ}$, near which the Americans have had their chief whaling and sealing stations for many years. ${ }^{1}$

On August 19 and 20, 1859 , Sir Leopold McClintock ran I50 miles down Prince Regent's Inlet, along the side, having an eastern aspect, to Bellot Strait, without seeing a bit of ice except one large iceberg, and returned by the same route in 1860 (August ro to I6), but on this occasion was stopped near Fury Point by ice, forced in by a strong easterly breeze of four days' duration; when the wind changed to west the obstruction was speedily removed, and there was no further difficulty. Dundee whalers have not infrequently visited Cresswell Bay in this locality, and killed whales there. So much for shores having an eastern aspect being navigable, notably that of Smith Sound.

The second passage from "Parry's Writings" I wish to comment upon is-

"These facts, when taken together, have long impressed me with the idea that there must exist in the Polar regions some general motion of the sea towards the zest, causing the ice to set in that direction, when not impelled by contrary winds or local or occasional currents,"

When it can be proved that permanent currents exist in the sea, irrespective of wind influence, we must naturally assume that the motion of the sea and of the ice floating on it is in the same direction.

The Resolute, one of Sir Edward Belcher's ships, abandoned near the south entrance of Wellington Channel in 1854, must have driven eastward for 300 miles through Barrow Strait and Lancaster Sound, into. Baffin's Bay, and was picked up far to the south by the Americans some years afterwards.

Sir Leopold McClintock in I859 and 1860 found Bellot Strait free from ice, and quite navigable, entering from the east, but impenetrably blocked with thick old ice-floes at its western extremity. In his chart is a note: "Bellot Strait, flood and permanent current to eastward."

Sir Edward Parry experienced a somewhat similar permanent easterly current in the Strait of the Fury and Hecla, as the following extract from Capt. Lyon's (who commanded one of Parry's ships) journal (p. 275) will show: "That there was a prevailing set from the westward we had long known, even before entering the strait, and we saw by the driving of the loose ice against an easterly wind that it ran with great force. As an extraordinary instance in point, the Hecla broke adrift on the $13^{\text {th }}$ in consequence of a piece of ice parting, and was carried (eastward) against a fresh easterly breeze, about a mile from the fast floe. All sail being set before the wind, we were nearly two hours in recovering this one mile, though to all appearance and by the $\log$ going between three and four knots through the water."

Here are examples of two permanent currents running to the east, through straits narrow, it is true, but the only passages known to exist in two lands extending about six degrees, or 360 miles north and south.

The conclusion to be arrived at seems to be, that the sea to the west of these lands is at a higher level than it is to the east of them, and consequently if the general motion of the "sea is towards the west," according to Sir Edward Parry's idea, it must, in the localities named, be moving in opposition to its own currents, or up hill.

4, Addison Gardens, November 26

J. RAE

ARE not the facts of ice-accumulations at "the western sides of seas or inlets," mentioned in your last number (p. 78 ), to be explained by reference to Baer's law for the flow of rivers? This law, corroborated by many observers in all parts of the world (see for instance NATURE, vol. xv. p. 207), states, as a simple consequence of the earth's rotation, the deviation to the right bank of all rivers of the northern hemisphere running north and south, i.e. to the west, if the flow is from the north, and to the east if from the south. Considered from this point of view, it may suffice that the masses of ice are borne by currents from the north, to account for the accumulations on the western borders of these currents, i.e. on "the eastern coast of any portion of land." I am well aware that the principle in question was applied to the theory of ocean-currents, long ere C. E.

I Along this shore, seal, walrus, and the right whale abounded in $\mathbf{2 8 4 6}$ 1847 , and 1853 , when I was there. In 1854 constant easterly winds kept the ice close to the land for ten days, so that few marine animals were seen during that time. 